DOI: 10.15587/2312-8372.2019.170289

\title{
Lymarenko 0. \\ INFLUENCE OF VENTILATED ENCLOSING STRUCTURES ON THE REGULATION OF HOUSE ENERGY SUPPLY
}

Об’єктом дослідження є розрахунок значення ходу змін внутрішньої температури в досліджуваному будинку з вентильованою (ВОК) та невентильованою огороджуючими конструкціями, в якому застосовувалося двоступеневе регулювання часу експлуатащї теплового пункту. Проведено комплексний аналіз енергоефективності будинку, $і$ в першу чергу, огороджуючих конструкиій. Показано, що для додаткової економії теплової енергї може бути використано регулювання центрального опалення. А також можливо виконувати регулювання в залежності від кліматичних умов, тобто теплова потужність котла або теплового пункту буде залежати від зміни температури зовнішнього повітря. Встановлено, що використання запропонованих у роботі науково обгрунтованих пропозицій суттєво підвищує теплову інерцію огороджуючих конструкцій. Завдяки щьому при вимкненні системи опалення будинок повільно охолоджується і нагрівається відносно швидко. Таким чином, можливо отримати заощадження, оскільки конструктивні елементи будівлі накопичують тепло. Встановлено суть оптимального регулювання температури, яка полягає в тому, щоб контролювати подачу теплової енергії в приміщення в такий спосіб, щоб відповідна внутрішня температура повітря була досягнута протягом певного часу. Виявлено, що для досягнення високої енергетичної ефективності будівлі, крім ї̈ термомодернізацї, необхідно підтримувати відповідні кліматичні умови всередині опалювальних приміщень. Встановлено фактори, які впливають на можливість регулювати температуру в середині приміщення в залежності від зміни температури зовнішнього повітря. Визначено коефіцієнт теплової акумуляції будівлі з використанням ВОК, який характеризує здатність загальної конструкцї будівлі акумулювати тепло і зменшувати коливання температури в опалюваних приміщеннях. В ході дослідження розроблено методику для опалювальних приміщень, яка дозволяє визначити послідовну зміну температури повітря в приміщеннях. За допомогою розроблених у роботі математичних моделей можна прогнозувати та оптимізувати теплові процеси в досліджуваних об'єктах.

ключові слова: теплова інериійність огороджуючих конструкцій, вентильовані фасади, теплообмін в огороджуючих конструкціях.

\section{Introduction}

In Ukraine, the average house consumes $260 \mathrm{kWh} / \mathrm{m}^{2}$. In Europe, a similar value ranges from 90 to $120 \mathrm{kWh} / \mathrm{m}^{2}$. The main reasons that lead to unjustifiably large heat losses in the housing and utilities sector are the imperfection of the existing building structures. A significant part of heat loss in houses during the heating period is due to the difference in temperature between the internal and external air (transmission loss of heat through external walling) and also as a result of air exchange processes. Thus, a significant increase in the energy efficiency of buildings and structures is one of the top priorities for researchers [1, 2]. The study of energy-efficient construction is reflected in [3-5]. The main objective of these researchers is in development of scientific and applied problems of improving the energy efficiency of buildings through their reconstruction or design. As well as reducing heat loss and minimizing the cost of heating residential premises in buildings with zero emissions; zero energy consumption and energy-efficient buildings.

Therefore, a comprehensive analysis of house energy efficiency, and in the first place, of enclosing structures is relevant. To further save heat energy, central heating regulation can be used. It is possible to make adjustments depending on weather conditions, that is, the heat output of the boiler or heat substation will depend on changes in the outdoor temperature. This line of research requires the creation of mathematical models with the help of which it is possible to predict and optimize thermal processes in the investigated objects. Thus, the object of research is the calculation of the value of the course of changes in the internal temperature in the investigated house with ventilated (VPS) and non-ventilated enclosing structures [6, 7], which used a two-stage regulation of the operation time of the substation. So, the aim of research is determination of the lowest achievable temperature inside the object and the rate at which the temperature returns to the initial value from the moment of the cooling stage using the specified types of enclosing structures.

\section{Methods of research}

First of all, let's determine the heat loss of the building [8]. The specific heat loss of the building (as the volumetric density of the heat flux penetrating through the construction partitions) $q, \mathrm{~W} /\left(\mathrm{m}^{3} \cdot{ }^{\circ} \mathrm{C}\right)$, for $1 \mathrm{~m}^{3}$ of the external volume is determined by the formula:

$$
q=\frac{P}{S}\left\{k_{w}+d\left(k_{w i n}-k_{w}\right)\right\}+\left(n_{t} k_{t}+n_{l} k_{l}\right) H^{-1}
$$

where $P$ - the outer perimeter of the building, $\mathrm{m} ; S$ - the projection area of the first floor of the building, $\mathrm{m}^{2} ; k_{w}, k_{\text {win }}$, 
$k_{t}, k_{l}$ - heat transfer coefficients for: external walls with VPS, windows, VPS above the top floor and lower floor (above the basement); $d$ - the proportion of glass surfaces; $H$ - building height, $\mathrm{m} ; n_{t}, n_{l}$ - coefficients that take into account the reduction of computational differences in the temperature of the top and lower ceilings with respect to the walls [9].

Heat loss through the VPS can be determined from the proposed mathematical models:

$$
\begin{aligned}
& n_{t} k_{t}=0.56 \cdot k_{w}, \\
& n_{l} k_{l}=0.34 \cdot k_{w} .
\end{aligned}
$$

The next step in the calculation is the determination of the thermal accumulation coefficient of the building using VPS. This coefficient characterizes the ability of the general construction of a building to accumulate heat and reduce temperature fluctuations in heated premises:

$$
T=\sum \frac{F \cdot c_{w}}{3.6 \cdot q \cdot V},
$$

where $F$ - the surface of the walls of the building or their individual parts (except for the glass surfaces), $\mathrm{m}^{2}$ :

$$
F=P \cdot H(1-d)
$$

$V$ - the external volume of the building or its individual parts, $\mathrm{m}^{3} ; c_{w}$ - equivalent heat capacity, $\mathrm{kJ} /\left(\mathrm{m}^{2} \cdot{ }^{\circ} \mathrm{C}\right)$.

Another problem is the development of a method for determining the air temperature in heated rooms.

The air temperature during its cooling is determined by the formula:

$$
t_{\text {a.in }}^{c}=\left(t_{a . i n}^{b . c}-t_{a . i n}\right)\left(J_{c}+\left(1-J_{c}\right) \exp \left(-\frac{Z}{\beta}\right)\right)+t_{a . i n},
$$

where $t_{a . \text { in }}^{c}$ - the temperature of the internal air at the beginning of the cooling stage; $J_{c}$ - relative heat output of the substation at the cooling stage. When $J_{c}=0$ :

$$
t_{\text {a.in }}^{c}=\left(t_{\text {a.in }}^{h}-t_{\text {a.in }}\right) 1\left(\exp \left(-\frac{Z}{\beta}\right)\right)+t_{\text {a.in }},
$$

where $Z$ - the number of hours that have passed since the beginning of the cooling stage; $\beta$ - thermal accumulation coefficient of the building:

$$
\beta=a_{c} T
$$

where $a_{c}$ - coefficient taking into account the time factor, which is determined by the formula:

$$
a_{c}=0.6+0.8 \cdot \exp \left(-\frac{1.5}{Z}\right)
$$

The air temperature during the heating phase is determined by the formula:

$$
t_{a . i n}^{h}=\left(t_{a . i n}^{b . h}-t_{a i n}\right)\left(x+(1-x) \exp \left(-\frac{Z_{h}}{\beta_{h}}\right)\right)+t_{a . i n},
$$

where $t_{a . i n}^{h}$ - the internal air temperature at the beginning of the heating stage; $Z_{h}$ - the number of hours elapsed since the beginning of the heating stage; $\beta_{h}$ - coefficient of accumulation of thermal energy in the heating stage:

$$
\beta=a_{h} T
$$

where $a_{h}$ - coefficient taking into account the factor at the heating stage is determined by the formula:

$$
a_{h}=0.2+0.4 \cdot \exp \left(-\frac{0.6}{Z_{h}}\right)
$$

$x$ - the relative heat flow supplied by the heating system, in relation to the thermal condition of the building, at the beginning of the heating stage:

$$
x=J_{h} \frac{t_{\text {s.in }}-t_{a . i n}}{t_{a . i n}^{a . h}-t_{a . i n}},
$$

where $t_{s . i n}$ - specified temperature of the indoor air in heated buildings; $J_{h}$ - relative heat output of the heating system at the heating stage (relative to the design capacity at a given outdoor temperature).

\begin{tabular}{|c|c|c|c|c|c|c|c|c|}
\hline \multirow{2}{*}{$\begin{array}{l}\text { Operation } \\
\text { mode }\end{array}$} & \multirow{2}{*}{$\begin{array}{c}\text { Heating system } \\
\text { load, \% }\end{array}$} & \multirow{2}{*}{$\begin{array}{c}\text { Stage implementation, } \\
\text { hours }\end{array}$} & \multirow{2}{*}{$Z$, hours } & \multirow{2}{*}{$a$} & \multicolumn{2}{|c|}{$b$} & \multicolumn{2}{|c|}{ Indoor temperature } \\
\hline & & & & & Common wall & VPS & Common wall & VPS \\
\hline Nominal & 100 & 20 & 0 & - & - & - & 22 & 22 \\
\hline Cooling & $\begin{array}{l}0 \\
0 \\
0 \\
0 \\
0 \\
0 \\
0 \\
0\end{array}$ & $\begin{array}{c}21 \\
22 \\
23 \\
24 \\
1 \\
2 \\
3 \\
4\end{array}$ & $\begin{array}{l}1 \\
2 \\
3 \\
4 \\
5 \\
6 \\
7 \\
8\end{array}$ & $\begin{array}{c}0.78 \\
0.98 \\
1.1 \\
1.15 \\
1.2 \\
1.22 \\
1.25 \\
1.27\end{array}$ & $\begin{array}{c}31.3 \\
39 \\
44 \\
46 \\
48 \\
49 \\
50.1 \\
52\end{array}$ & $\begin{array}{l}33 \\
41 \\
47 \\
48 \\
50 \\
51 \\
53 \\
54\end{array}$ & $\begin{array}{c}21.5 \\
21 \\
20.6 \\
20 \\
19.6 \\
19.1 \\
18.6 \\
18\end{array}$ & $\begin{array}{c}22 \\
22 \\
21.7 \\
21.4 \\
21.1 \\
21 \\
20.7 \\
20.3\end{array}$ \\
\hline Heat & $\begin{array}{l}150 \\
150 \\
150 \\
150\end{array}$ & $\begin{array}{l}5 \\
6 \\
7 \\
8\end{array}$ & $\begin{array}{l}1 \\
2 \\
3 \\
4\end{array}$ & $\begin{array}{c}0.4 \\
0.5 \\
0.53 \\
0.55\end{array}$ & $\begin{array}{l}17 \\
20 \\
21 \\
22\end{array}$ & $\begin{array}{l}18 \\
20 \\
22 \\
23\end{array}$ & $\begin{array}{l}19 \\
20 \\
21 \\
22\end{array}$ & $\begin{array}{c}21 \\
22 \\
\text { nominal } \\
\text { mode }\end{array}$ \\
\hline
\end{tabular}

The following values were determined for the architectural data of the investigated object and the outdoor air temperature of $-5{ }^{\circ} \mathrm{C}$ :

1. Specific heat loss of a building: $0.099 \mathrm{~W} /\left(\mathrm{m}^{3} \cdot{ }^{\circ} \mathrm{C}\right)$ [10].

2. Constant $T=40.193 \mathrm{~h}$.

3. $x=1.936$.

4. The temperature state of the house with two-stage regulation at the heating stage at $J_{h}=1.65$ is presented in Table 1.

Table 1

Calculations for the presented methodology 
In reality, the relative heat output of the heating system when the cooled object is heated is higher than nominal [11]. When turning on the circulation pumps, there is a significant increase in thermal power due to a significant difference in water temperature at the supply and return. Therefore, in the proposed method there was a corrected value $J_{h}=3$ for the first hours of heating the rooms with the given conditions. In the following hours, the normal level of the relative heat output of the system was $J_{h}=1$ and $x=1.17$. The results are shown in Table 1 . If compare the results obtained for a conventional insulated wall and VPS, the heating of the VPS protection will last 2 hours, that is, two times shorter, or the heat output can be reduced.

\section{Research results and discussion}

Based on the calculations, a diagram (Fig. 1) of the change in the internal temperature in the investigated object is created.

Temperature sensors - thermocouples - are placed in the investigated room at a height of $1.5 \mathrm{~m}$ from the floor and at a distance of $0.15 \mathrm{~m}$ from the inner walls. Also the thermocouples in the middle of the room and one outside are installed. Measurements were taken between 20:00 and 7:00. In both experiments, the heating unit was completely turned off (from 20:00 to 5:00) on January 13 and 14, 2017 and January 16 and 17, 2017, and then turned on as usual. In the first experiment, the average temperature was $4{ }^{\circ} \mathrm{C}$, in the second $-2{ }^{\circ} \mathrm{C}$.

The results of temperature measurements are presented in Fig. 2, 3, respectively, for two repetitions of the experiment (experiment I and II).
Indoor temperature, ${ }^{\circ} \mathrm{C}$

30
25
20
15
10
5
0
-5
-10

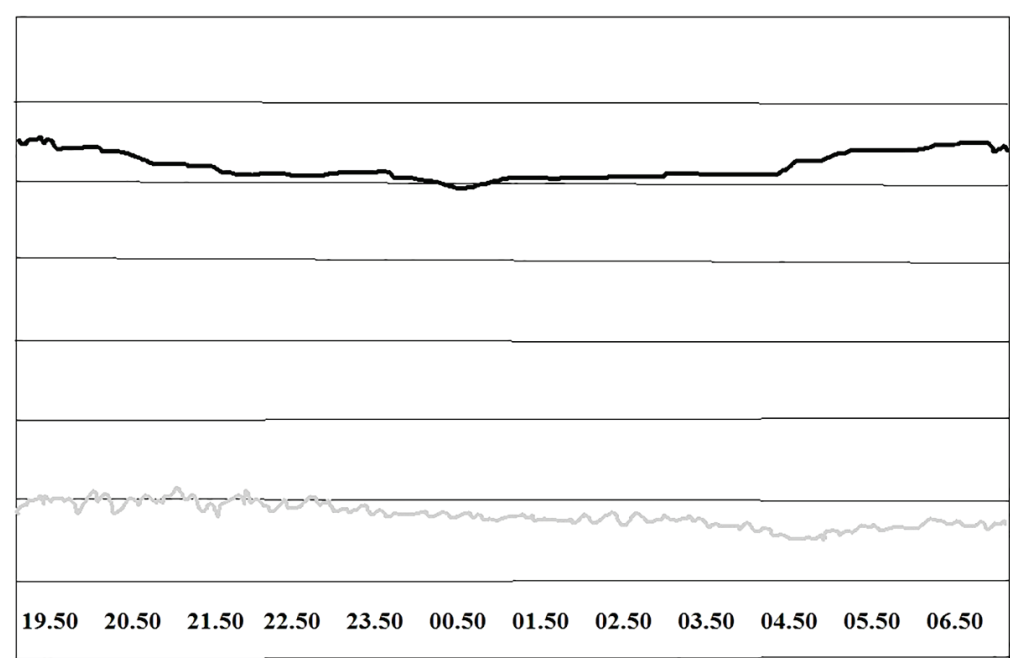

Time, hours

Indoor temperature, ${ }^{\circ} \mathrm{C}$

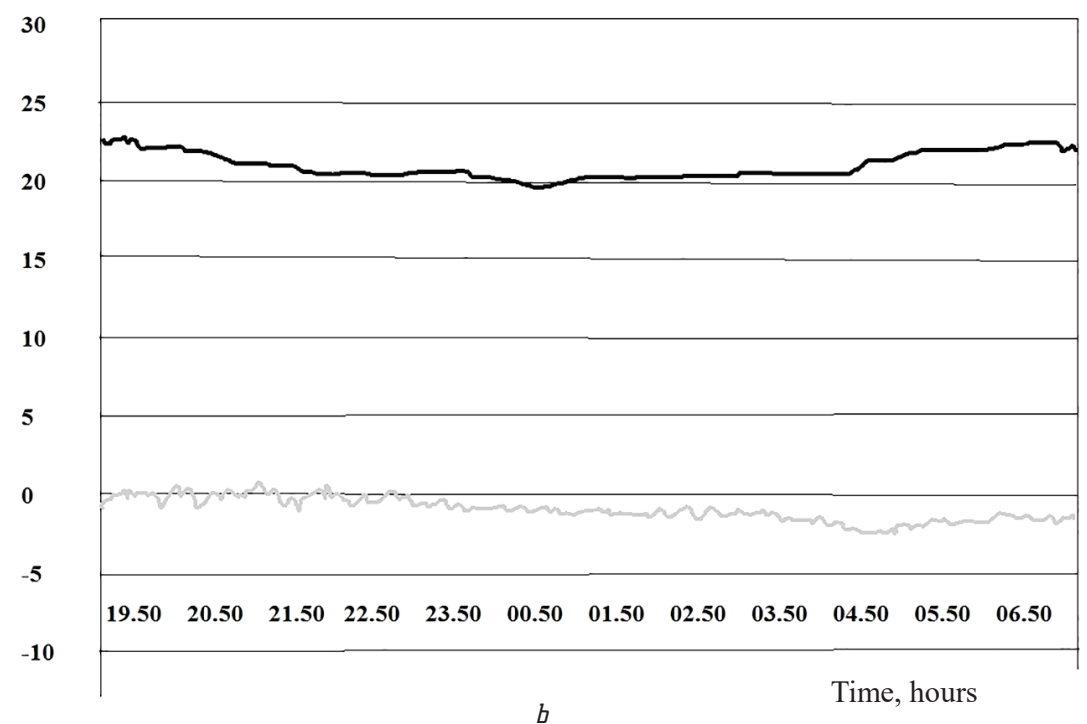

Fig. 2. The results of temperature measurements

$a$ - when power off; $b$ - when starting the heating point; - - external temperature; - internal temperature

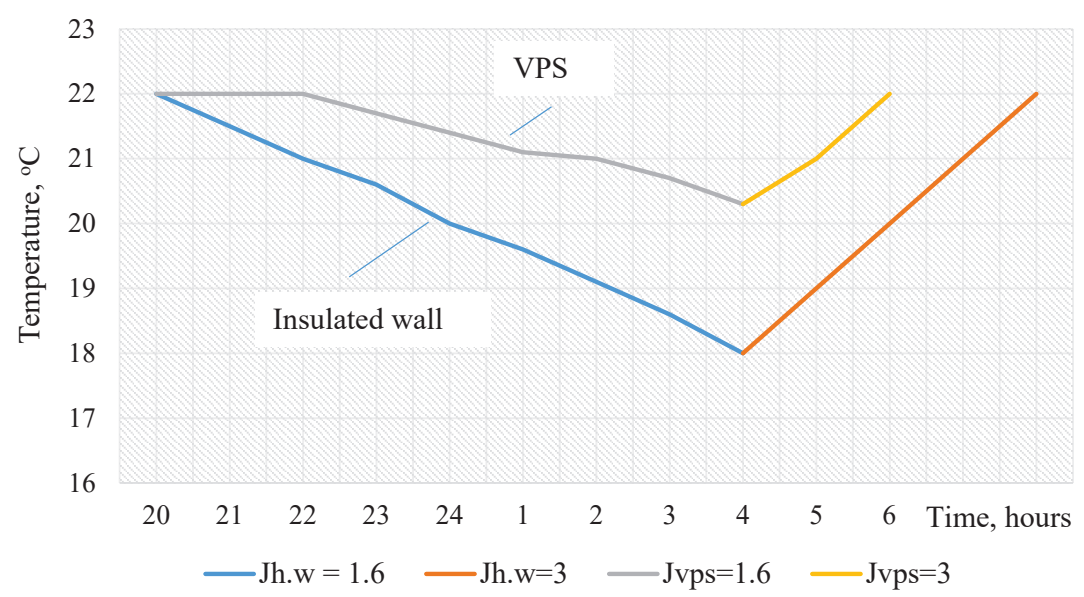

Fig. 1. Graph of temperature change in the room
In the second experiment, the internal air temperature decreased less, because the external temperature was higher.

Fig 2, $a, b$ shows a slow drop in temperature when the power is turned off in the heat node, and then its rapid growth after the launch of the heat point.

Calculations performed by the new method were compared (Fig. 3) with the results of two series of the above experiment.

The presented method describes the temperature change in the room of the investigated object, aimed at determining the lowest achievable tempe- 
rature level and the rate of return to the original thermal conditions. Of course, the technique takes into account the change in the thermal inertia of the house when using the VPS and the change in external climatic conditions.

Indoor temperature, ${ }^{\circ} \mathrm{C}$

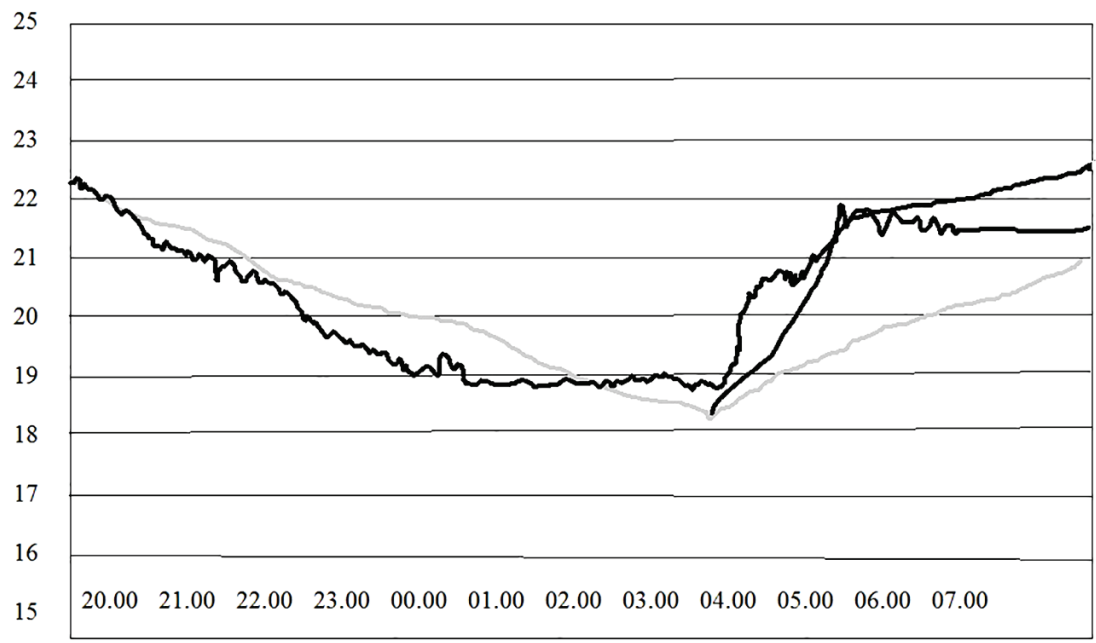

Time, hours

Indoor temperature, ${ }^{\circ} \mathrm{C}$

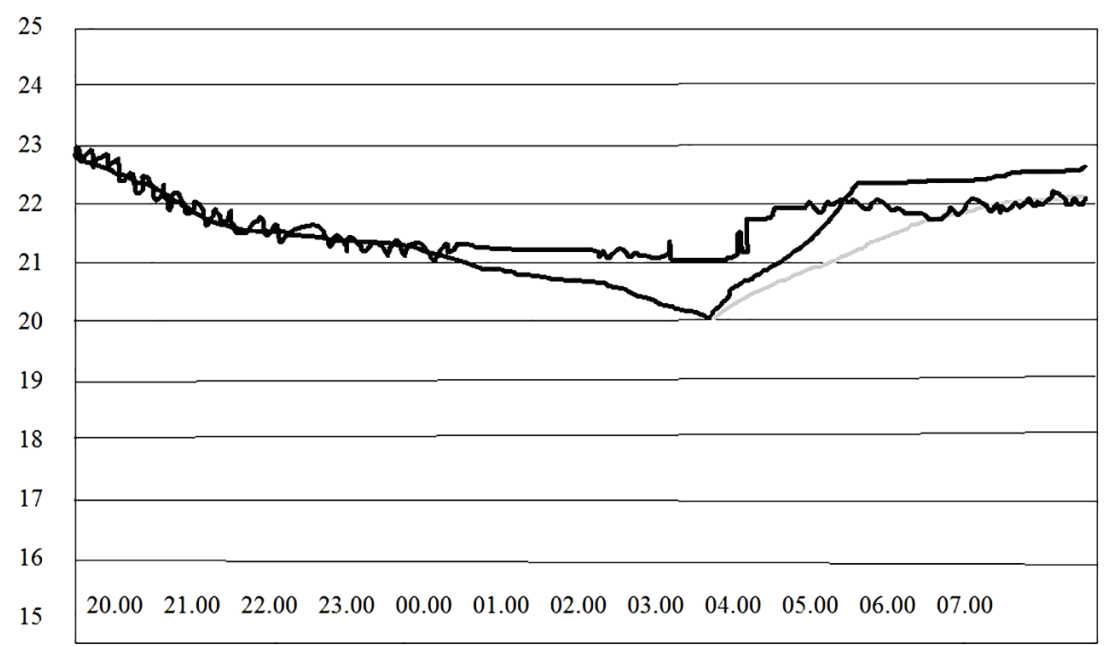

$b$ science-based proposals significantly increases the thermal inertia of the enclosing structures, so that when the heating system is turned off, the house slowly cools and heats up relatively quickly. In this way, savings can be obtained as the building's structural elements accumulate heat.

\section{References}

1. Dolinskyi A. A., Basok B. I. Stvorennia eksperymentalnoho enerhoefektyvnoho budynku pasyvnoho typu: proceeding // Enerhetychna bezpeka na transporti: pidvyshchennia enerhoefektyvnosti, znyzhennia zalezhnosti vid pryrodnoho hazu. Kyiv, 2014. P. 26-30.

2. Passive houses in Ukraine and countries of UIC / Bozhko I. K., Lysenko O. N., Goncharuk S. M., Kalinina M. F. // Industrial Heat Engineering. 2018. Vol. 37, Issue 1. P. 69-81. doi: http:// doi.org/10.31472/ihe.1.2015.09

3. Dynamic Thermal Performance Simulation of an Improved Passive Solar House with Trombe Wall / Zhao J., Chen B., Liu J., Wang Y. // Proceedings of ISES World Congress 2007 (Vol. I - Vol. V) Beijing, 2008. P. 2234-2239. doi: http:// doi.org/10.1007/978-3-540-75997-3 451

4. Heat Transfer in Buildings: Application to Solar Air Collector and Trombe Wall Design / Boyer H., Miranville F. Bigot D., Guichard S., Ingar I. et. al. // Evaporation, Condensation and Heat Transfer. 2011. P. 227-244. doi: http:// doi.org/10.5772/23025

5. Lobna M., Dehmani L. A numerical study of heating and cooling by a Trombe wall in Tunisia // The fifth International Renewable energy congress. Tunisia: Hammamet, 2014. doi: http://doi.org/ 10.1109/irec.2014.6826940

6. Basok B. I. Eksperymentalnyi budynok pasyvnoho typu // Enerhoefektyvnist $\mathrm{v}$ budivnytstvi ta arkhitekturi. 2014. Issue 6. P. 3-8.

7. Basok B. I., Nakorchevskii A. I. Modelirovanie teploperedachi cherez naruzhnoe ograzhdenie zdanii s uchetom nepreryvnogo deistviia klimaticheskikh faktorov // Stroitelnye konstruktsii. 2014. Issue 80. P. 113-120.

8. Dolyin A. A. Creation of an experimental energy-efficient passive type Building: proceedings // Energy Security in Transport: Enhancing Energy Efficiency,

\section{Conclusions}

The essence of the optimal temperature control is established, which is in controlling the flow of thermal energy into the room, so that the corresponding internal air temperature is reached within a certain time. A technique is developed for heated rooms, which allows determining the sequential change of air temperature in rooms. For the mathematical model developed in this work, the thermal accumulation coefficient of a building using VPS is determined, which characterizes the ability of the general structure of the building to accumulate heat and reduce temperature fluctuations in heated premises. The use of the proposed Decreasing Dependence on Natural Gas. Kyiv, 2014. P. 26-30.

9. Stvorennia eksperymentalnoho enerhoefektyvnoho budynku pasyvnoho typu «nul enerhii»/ Honcharuk S. M., Kalinina M. F., Bozhko I. K., Kuzhel L. M., Lysenko O. M. // Promyslova Teplotekhnika. 2014. Vol. 36, Issue 3. P. 88-95.

Time, hours

\section{- experiment;}

10. Ratushniak H. S., Anokhina K. V. Analiz metodiv matematychnoho modeliuvannia dlia vyznachennia teploperedachi cherez bahatosharovi zakhysni konstruktsii // Suchasni tekhnolohii, materialy i konstruktsii v budivnytstvi. Vinnytsia: UNIVERSUMVinnytsia, 2007. P. 137-141.

11. Protasevich A. S., Kalina L. M., Krutilin A. B. Voprosy teplotekhnicheskogo rascheta naruzhnykh teploizolirovannykh sten zdanii s ekranom i ventiliruemoi prosloikoi // Stroitelnii rynok. 2003. Issue 20. P. 1-5.

Lymarenko Oleksiy, Lecturer, Gogol Mirgorod Art and Industrial College of the Poltava National Technical Yuriy Kondratyuk University, Mirgorod, Poltava region, Ukraine, e-mail: tonus822@gmail.com, ORCID: http://orcid.org/0000-0002-1714-4508 